\title{
Introduction to special issue dedicated to the 35th anniversary of the joint section on tumors
}

\author{
Isabelle M. Germano ${ }^{1} \cdot$ Jason Heth ${ }^{2} \cdot$ Pamela S. Jones $^{3} \cdot$ Manish K. Aghi ${ }^{4}$
}

Received: 26 February 2020 / Accepted: 23 April 2020

(c) Springer Science+Business Media, LLC, part of Springer Nature 2020

\begin{abstract}
The American Association of Neurological Surgeons (AANS)/Congress of Neurological Surgeons (CNS) Joint Section on Tumors was formed in December of 1984 as the first professional organization devoted to the study and treatment of brain tumors. One year earlier, the Journal of Neuro-Oncology had been established and went on to be sponsored by the Joint Section on Tumors. To celebrate the 35th anniversary of the founding of the Section, we are thrilled to bring you this special issue of Journal of Neuro-Oncology in which current leaders of the Joint Section on Tumors highlight their work and the work of others that have led to significant recent advances in the management of tumors of the central nervous system.
\end{abstract}

Keywords Tumor section $\cdot$ History $\cdot$ Anniversary $\cdot$ Meningioma $\cdot$ Immunotherapy

The AANS/CNS Joint Section on Tumors was formed in December of 1984, when it was the first professional organization devoted to the study and treatment of brain tumors. One year earlier, the Journal of Neuro-Oncology had been established and went on to be sponsored by the Joint Section on Tumors. To celebrate the 35th anniversary of the founding of the Section, we are thrilled to bring you this special issue of Journal of Neuro-Oncology in which current leaders of the Joint Section on Tumors highlight their work and the work of others that have led to significant recent advances in the management of tumors of the central nervous system.

Since the founding of the Section in 1984, there has been steady growth in overall membership, with 2020 total enrollment numbers reaching the highest to date at 3073 members (Fig. 1). This reflects a six-year stretch of consistent increase in the number of total members. Active members serve as

Manish K. Aghi

manish.aghi@ucsf.edu

1 Mount Sinai Department of Neurological Surgery, New York, NY, USA

2 Department of Neurosurgery, University of Michigan, Ann Arbor, MI, USA

3 Massachusetts General Hospital Neurosurgery Service, Boston, MA, USA

4 UCSF Neurosurgery, UCSF Department of Neurological Surgery, 505 Parnassus Avenue Room M779, San Francisco, CA, USA the core of the Section membership and leadership and contribute to the majority of the Section's operating budget. Within organized neurosurgery, since the 1990s, the Tumor Section has consistently remained as one of the three largest Sections, and, as of the beginning of 2019, the Tumor section was the second largest section behind Spine and ahead of Trauma. Recruitment efforts center largely around the annual CNS and AANS meetings, where the Tumor Section hosts a reception jointly with the Young Neurosurgeons committee.

The Section eventually wished to establish a scientific meeting. In the AANS and the CNS organizations, there was a concern that other joint section meetings had created a disincentive to neurosurgeon attendance at the AANS and CNS Annual Meetings. In an effort to address those concerns, the Joint Section on Tumors proposed to establish a scientific meeting in conjunction with the AANS or CNS meetings biennially. This proposal was ultimately selected, and the first biennial satellite session was held in Chicago, IL on October 6th and 7th, 1994, in conjunction with the CNS Annual Meeting. Mitchel Berger MD was the Scientific Chair for this first meeting and Peter Black, MD, PhD was the Section Chair during this meeting. Session topics for this first meeting included Oncogenesis, Invasion and Metastasis, and New Therapeutic Concepts. The second symposium occurred in Montreal, Quebec on October 3rd and 4th, 1996. The Scientific Chair for this meeting was Raymond Sawaya, MD and the Section Chair was William Chandler, 
Fig. 1 Tumor Section membership over time. Graph showing total membership figures for the AANS/CNS Joint Section on Tumors

\section{Total membership}

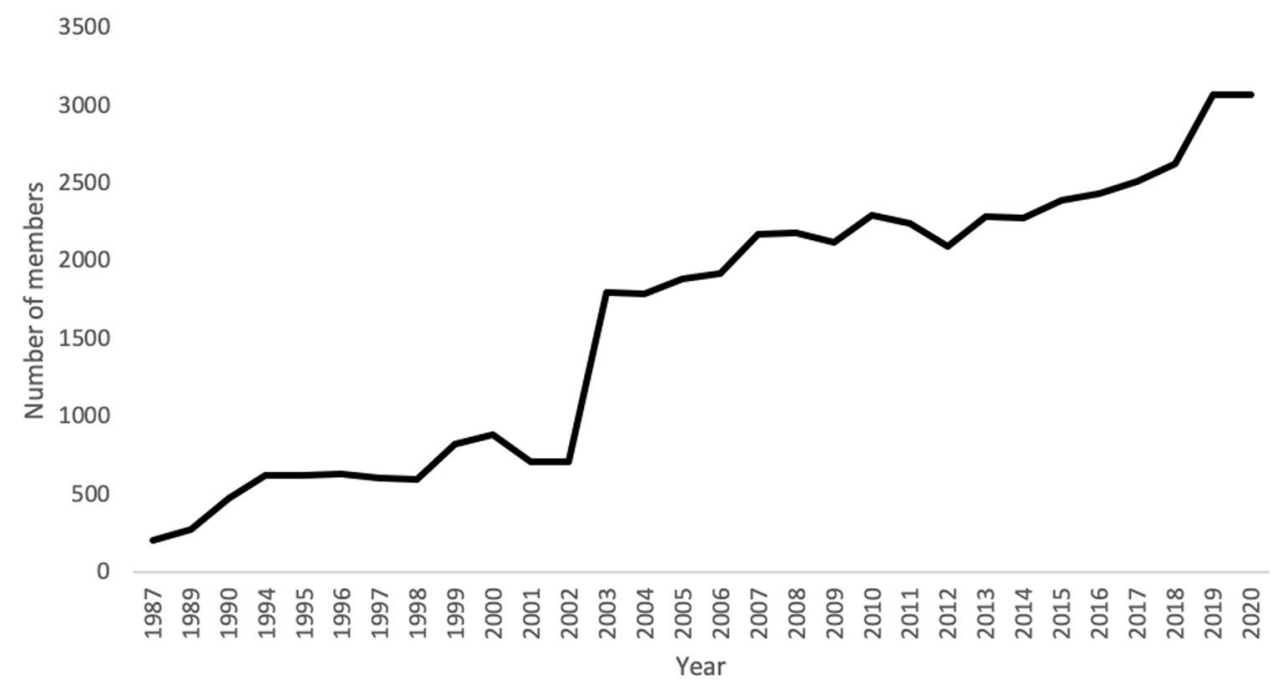

MD. This meeting was the first and so far, only symposium held outside the United States. Since then, meetings have generally occurred about every two years, however when meetings occasionally switch from the AANS to the CNS or vice versa, the time interval between symposia is either $1 \frac{1}{2}$ years or $2 \frac{1}{2}$ years. Two other symposia are also of particular note. The Symposia in 2009 in New Orleans, LA and 2011 in Orange County, CA occurred in conjunction with the Annual
Meetings of the Society of Neuro-Oncology (SNO). Since then, the symposia have returned to occurring in conjunction with the AANS or CNS Annual Meetings (Table 1). The 14th Satellite Symposium is scheduled for September 11th and 12th, 2020 in Miami, FL. The theme is "Neurosurgical Oncology 2020: A Vision for the Future". Of note, each Satellite Symposium has chosen two or more special topics to focus on with panel discussions and invited talks and the

Table 1 Satellite Symposium Meeting Dates, Locations, and Presiding Officers

\begin{tabular}{|c|c|c|c|c|}
\hline Number & Dates & Location (Associated meeting) & Scientific chair(s) & Section chair \\
\hline 1 & October 6-7, 1994 & Chicago, IL (CNS) & Mitchel Berger, MD & Peter Black, MD, PhD \\
\hline 2 & October 3-4, 1996 & Montreal, Quebec (CNS) & Raymond Sawaya, MD & William Chandler, MD \\
\hline 3 & April 30-May 1, 1998 & Philadelphia, PA (AANS) & James T. Rutka, MD, PhD & Mark Bernstein, MD \\
\hline 4 & April 13-14, 2000 & San Francisco, CA (AANS) & Ronald Warnick, MD & Joseph Piepmeier, MD \\
\hline 5 & April 11-12, 2002 & Chicago, IL (AANS) & Nalin Gupta, MD, PhD & James Rutka, MD, PhD \\
\hline 6 & October 21-22, 2004 & San Francisco, CA (CNS) & Frederick Lang, MD & Raymond Sawaya, MD \\
\hline 7 & April 13-14, 2007 & Washington, DC (AANS) & Andrew Parsa, MD, PhD & Ronald Warnick, MD \\
\hline 8 & October 22-24, 2009 & $\begin{array}{l}\text { New Orleans, LA (CNS); Joint } \\
\text { with Society for Neuro- } \\
\text { Oncology }\end{array}$ & $\begin{array}{l}\text { Randy Jensen, MD, PhD Frederick } \\
\text { Lang, MD (SNO) }\end{array}$ & $\begin{array}{l}\text { Michael McDermott, MD } \\
\text { (2007-2009) Jeffrey Bruce, MD } \\
\text { (2009_2011) }\end{array}$ \\
\hline 9 & November 17-20, 2011 & $\begin{array}{l}\text { Orange County, CA; Joint } \\
\text { with Society for Neuro- } \\
\text { Oncology }\end{array}$ & $\begin{array}{l}\text { Michael Vogelbaum, MD, PhD Freder- } \\
\text { ick Lang, MD (SNO) }\end{array}$ & $\begin{array}{l}\text { Jeffrey Bruce, MD (2009—2011) } \\
\text { Frederick Lang, MD (2011— } \\
\text { 2013) }\end{array}$ \\
\hline 10 & April 26-27, 2013 & New Orleans, LA (CNS) & $\begin{array}{l}\text { Nader Sanai, MD, Michael Vogel- } \\
\text { baum, MD, PhD, Isaac Yang, MD }\end{array}$ & Frederick Lang, MD (2011—2013) \\
\hline 11 & May $1-2,2015$ & Washington, DC (AANS) & $\begin{array}{l}\text { Orin Bloch, MD, Gavin Dunn, MD, } \\
\text { PhD }\end{array}$ & Frederick Barker, MD \\
\hline 12 & September 23-24, 2016 & San Diego, CA (CNS) & $\begin{array}{l}\text { Chetan Bettegowda, MD, Brian } \\
\text { Nahed, MD }\end{array}$ & Steve Kalkanis, MD \\
\hline 13 & October 5-6, 2018 & Houston, TX (CNS) & Jeff Weinberg, MD, Isaac Yang, MD & Manish Aghi, MD, PhD \\
\hline 14 & September 11-12, 2020 & Miami, FL (CNS) & $\begin{array}{l}\text { Ian Dunn, MD, Michael Vogelbaum, } \\
\text { MD, PhD }\end{array}$ & Jason Sheehan, MD, PhD \\
\hline
\end{tabular}

References: Barker and Linskey, 2004; Lang and Barker, 2014; Tumor Section Newsletters 
only topics chosen more than once for these meetings in the past decade have been immunotherapy, meningioma biology, and skull base surgery, three of the 15 topics focused on in the articles in these issues.

Another major goal of the AANS/CNS Joint Section on Tumors is promoting education and fostering research in the field of brain and spine tumors. In support of these goals, the section recognizes excellence in different categories of clinical and research aspects of brain and spine tumor by awarding 12 awards at each AANS and 10 at each CNS meeting annually. While many of these awards are designated for specific topics, certain trends emerge in the topics of award winning abstracts outside of the pre-designated topics, with immunotherapy, skull base endoscopy, and molecular biology of meningiomas emerging in recent years as the three most common such topics, representing $15 \%, 13 \%$, and $8 \%$ of the subjects of award-winning abstracts. As mentioned above, these topics also trended as popular topics for the Section's satellite symposium in the past decade and, as such, were among the 15 topics chosen to highlight in this Special Issue.

In addition to those three topics, this special issue highlights other important topics in neurosurgical oncology, including tumor diagnosis (Raman spectroscopy), non-invasive treatments (radiosurgery and LITT), minimally invasive procedures (convection-enhanced delivery, endoscopic skull base surgery, fluorescence guided surgery for pituitary adenomas, and surgery through tubular ports), open surgical treatments (insular gliomas), neurosurgical procedures for tumors that are done to investigate research questions (neurosurgical clinical trials and phase 0 clinical trials), and research about neurosurgical procedures (guidelines and membership surveys). We hope you enjoy these articles written in celebration of the 35th anniversary of the Joint Section on Tumors.

Funding This study was not funded.

\section{Compliance with Ethical Standards}

Conflict of interest All authors report no conflicts of interest.

Research involving human and animal rights This article does not contain any studies with human participants or animals performed by any of the authors.

Publisher's Note Springer Nature remains neutral with regard to jurisdictional claims in published maps and institutional affiliations. 